\title{
A SURVEY DONE AMONG DENTAL STUDENTS ON THEIR KNOWLEDGE IN ENDODONTIC MICROBIOLOGY
}

\author{
Dobrina Karayasheva, Elka Radeva. \\ Department of Conservative Dentistry, Faculty of Dental Medicine, Medical \\ University - Sofia, Bulgaria.
}

\begin{abstract}
Introduction: Knowledge of endodontic microbiology and microbial organization in the root canal system is important for understanding the disease process and for establishing effective antimicrobial therapeutic strategies.

The purpose of this survey is to summarize the knowledge of 5-year Bulgarian dental students about endodontic infections and their treatment.

Materials and Methods: The survey includes students from FDM-Sofia who were asked to answer 11 questions online. The questions relate to species characteristics and microbial count of microorganisms in infected root canals in primary and persistent infections, apical periodontitis and overtreatment. Additional information on the respondents' age and gender has been collected and the data has been analyzed using descriptive statistic.

Results: Ninety-three students participated in the survey, $31.52 \%$ of whom reported that over 300 microbial strains could be isolated from infected root canals. In apical periodontitis $8.7 \%$ reported $20-40$ strains. $47.83 \%$ indicated that the microbial count in an infected root canal in a primary endodontic infection is $10^{5}$. Streptococcus spp. is indicated as the main reason for persistent infections by $53.26 \%$ and Enterococcus faecalis by $25 \% .40 .22 \%$ have chosen Streptococcus spp. as the primary species associated with overtreatment, $27.17 \%$ have chosen Peptpstreptococcus and $19.57 \%$ - Enterococcus faecalis. $85.87 \%$ associate pain with Peptpstreptococcus and Prevotela spp. $68.48 \%$ consider plating onto agars as the main method for isolating and identifying microorganisms. The results are presented graphically and represent the percentage distribution of the answers.
\end{abstract}

Conclusion: Students' knowledge of species characteristics of microorganisms in various nosological units associated with infected root canals should be increased.

Keywords: Endodontic infections, endodontic microbiology, apical periodontitis, student training, survey.

\section{INTRODUCTION}

Apical periodontitis is essentially an inflammatory disease of microbial etiology of the apical periodontium. The bacterial profiles of the endodontic microbiota vary between individuals. This indicates that apical periodon- titis has a heterogeneous etiology, and multiple bacterial combinations in the root canal can cause apical periodontitis. To achieve successful endodontic treatment, it is important to know the specific bacterial species characteristic of endodontic infections and the specific antimicrobial agents, antibiotics included, that can destroy the bacteria present or at least inhibit their growth [1,2,3].

According to the guidelines of the European Society of Endodontology (ESE 2013), a graduating European dentist's knowledge should be adequately grounded in basic and applied science for safe clinical practice in Dental Medicine and Endodontics in particular [4, 5]. According to these prescriptions, graduating students should not only have knowledge of endodontic microbiology and the microorganisms found in dental pulp diseases but should also be competent enough to treat these infections by knowing and applying pharmacological agents, including antibiotics, according to their mechanisms of action. However, lack of sufficient knowledge of the problem and inappropriate prescription schemes and use of medications have been established both among European dentists $[4,5,6,7,8]$ and dentists throughout the world.

Puryer, J. et al. have found a direct relationship between the level of clinical experience of the students and the confidence they show when having to perform root treatments [9].

The review of specialized scientific literature shows that there is scarce information about research done among trainee dental students regarding their knowledge in the field of endodontic microbiology.

The purpose of this survey among students of dental medicine (in their fifth, last but one year of study) is to summarize their knowledge of endodontic microbiology.

\section{MATERIALS AND METHODS}

Ninety-three Bulgarian students $(\mathrm{n}=93)$, aged 2035 , took part in the survey voluntarily, without payment and after giving their informed consent. The survey was conducted during a regular lecture class, and the absent students were not included in it. The students were asked to answer 11 questions online through a web link. The data were analyzed using SPSS (Statistical Package for Social Sciences) - descriptive statistics and the chi-square test. 
Data description was carried out by frequency graphs. When obtaining the numerical representation by percentages, the total number of answers for each question was taken into account.

\section{RESULTS}

The demographic data of the 93 respondents is shown in Figures 1 and 2: male $(n=37)$ represent $39.78 \%$ and female $(n=56)-60.22 \%$ of all the participants. The average age of the respondents is 23 years (fig. 2). All respondents are students from the Faculty of Dental Medicine of the Medical University, Sofia (Bulgaria).

Fig. 1. Percentage distribution of respondents by sex

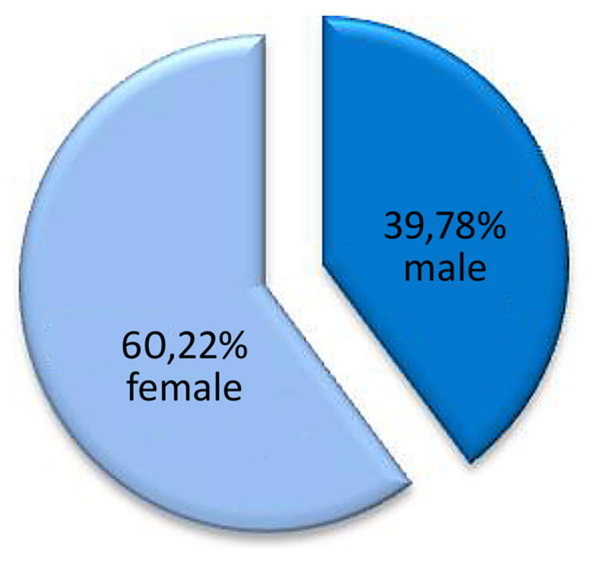

Fig. 2. Percentage distribution of respondents by age

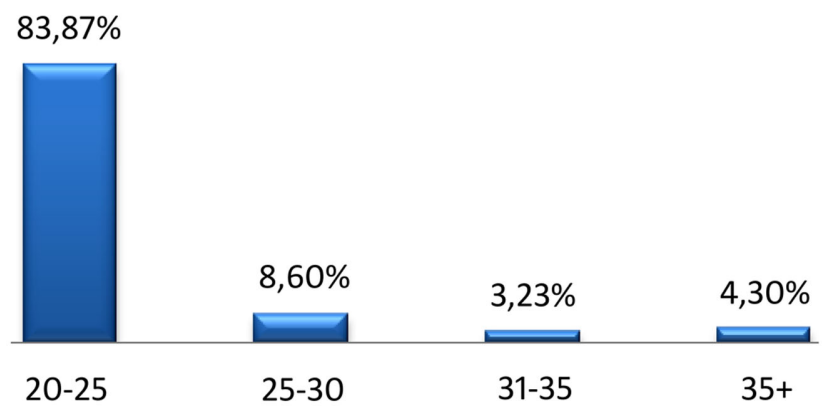

Epidemiological studies indicate that over 300 different microbial strains can be found in infected root canals, usually in combinations. Theoretically, each of them has the potential to be an endodontic pathogen, but not every one of them can adapt and survive in the conditions of the root canal. This is the answer given by $31.52 \%$ of the students to the question, "How many microbial strains can be found in infected root canals?" The answer, "Up to 200 microbial strains", is chosen by $27.17 \%$, up to 100 - by $23.91 \%$, and $20-40$ - by $17.39 \%$ of the respondents (fig. 3 ).
Fig. 3. Percentage distribution of participants' responses as regards the number of microbial strains that can be found in infected root canals

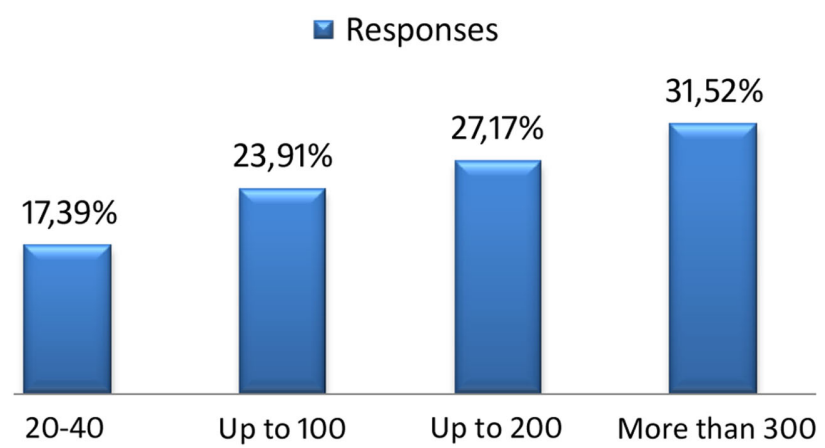

About 20-40 microbial strains are most commonly isolated from infected root canals and associated with apical periodontitis, with 10-12 of them being predominantly anaerobic species $[1,10,11]$. As regards apical periodontitis, $41.30 \%$ of the students have indicated that the isolated microbial strains could be over 300 , and only $8.70 \%$ have indicated $20-40$ microbial strains (fig. 4).

Fig. 4. Percentage distribution of responses concerning the number of microbial strains that can be isolated from infected root canals in apical periodontitis

\section{Responses}

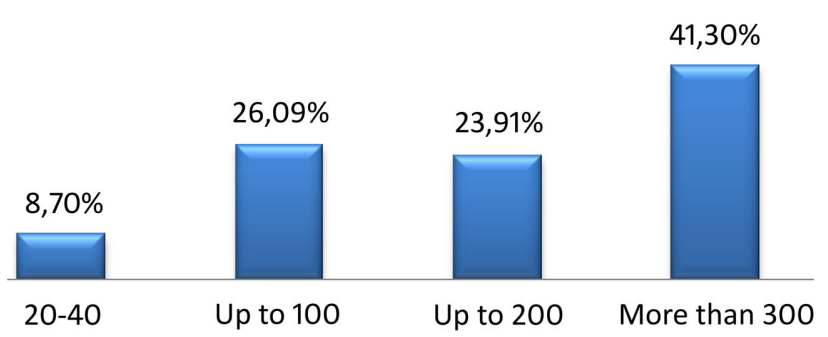

The microbial count of bacterial cells in an infected root canal is between $10^{3}$ and $10^{8} \mathrm{CFU}[1,12,13]$. The highest percentage of respondents, $47.83 \%$, have indicated that the microbial count in primary endodontic infection is up to $10^{5} \mathrm{CFU}$, and $31.52 \%$ have indicated the response of $10^{8} \mathrm{CFU}$ (fig. 5). 
Fig. 5. Percentage distribution of responses regarding microbial count in an infected root canal in a primary endodontic infection

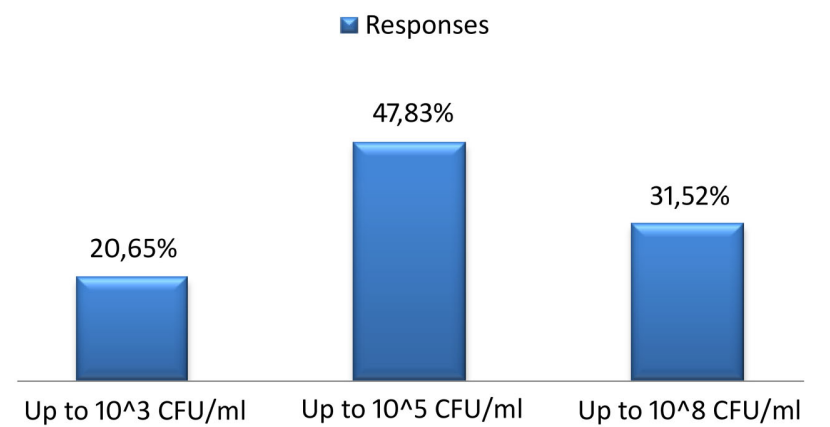

Fig. 6. Percentage distribution of responses regarding the bacterial species that is most commonly
Since it is impossible to investigate students' knowledge of all types of endodontic pathogens in one survey, we have chosen to focus on the following types of microorganisms: Streptococcus spp., Peptostreptococcus spp., Actinomyces spp., Enterococcus faecalis and Candida albicans.

$53.26 \%$ of the respondents in this survey have chosen the microaerophilic Streptococcus spp. as the most common cause of persistent endodontic infections, $25.00 \%$ have chosen Enterococcus faecalis, $9.78 \%$ - Peptostreptococcus spp., $7.61 \%$ - Actinomyces spp., and $4.35 \%$ - Candida albicans (fig. 6).

\section{associated as the main cause of persistent endodontic infections}

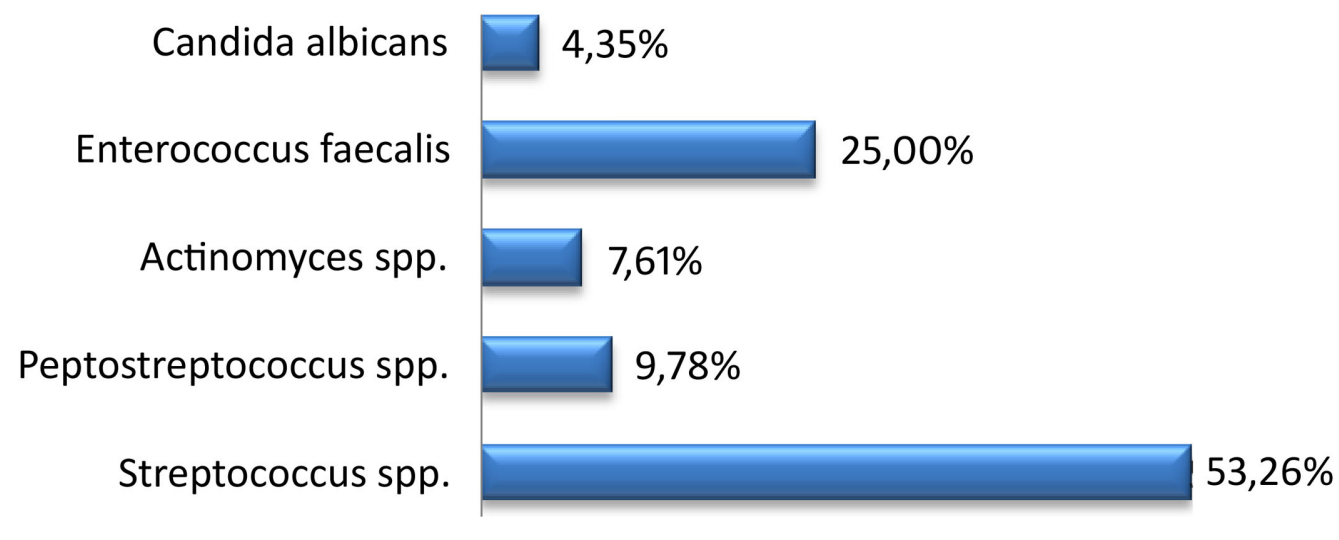

Streptococcus spp. and Enterococcus spp. are facultative anaerobes that are referred to the potentially virulent and invasive pathogens (isolated from both teeth with a primary endodontic infection and after overtreatment). Actinomyces spp. are isolated in $10 \%$ of the infected root canals and mostly in cases of failed endodontic treatment $[1,14,15]$.
The greatest part $(40.22 \%)$ of the respondents believe that Streptococcus spp. is most commonly associated with the failure of the treatment carried out, which leads to overtreatment. $27.17 \%$ have indicated Peptostreptococcus spp., $19.57 \%$ - Enterococcus faecalis, $11.96 \%$ Actinomyces spp., and $1.09 \%$ - Candida albicans (fig. 7).

Fig. 7. Percentage distribution of responses regarding the bacterial species that is most commonly associated with as the main cause of root treatment failure and the need of overtreatment subsequently

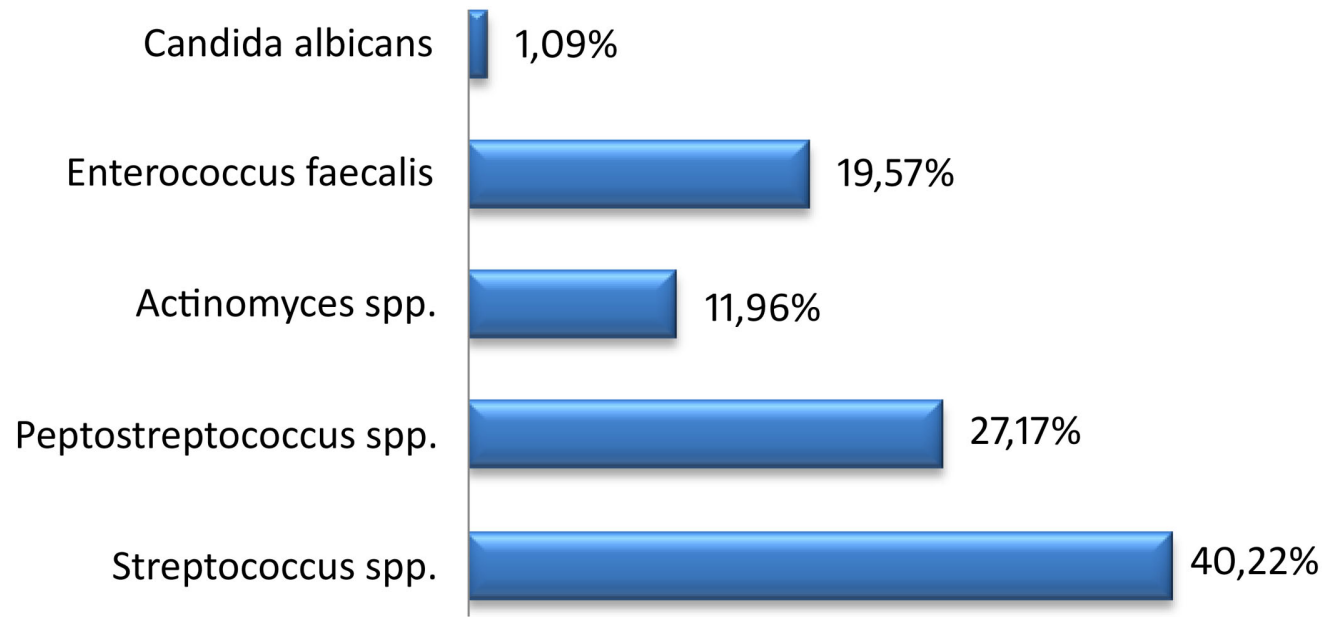


Culture studies have proved that E. faecalis is the most frequent species in root canals of endodontically treated teeth, with the prevalence reaching up to $90 \%$ of the cases. Teeth with prepared root canals are approximately nine times more likely to harbor E. faecalis than teeth with primary infections. E. faecalis can often be isolated from teeth treated in multiple visits and/or teeth left open for drainage. Thus, E. faecalis may be a secondary invader that succeeds in colonizing the root canal, resists treatment and causes a secondary infection that then becomes persistent. $E$. faecalis is usually the most frequent species that is isolated from human clinical specimens and represents 80-90\% of the clinically significant enterococcal isolates [16].

Pain, as a symptom, is most often associated with the presence of Peptostreptococcus spp. and Prevotella spp. The swelling and presence of an exudate in the root canal are associated with a combination of Eubacterium, Peptostreptococcus spp. and Prevotella spp. [1].

The presence of Peptostreptococcus spp. and Prevotela spp. was indicated as the cause of pain in infected root canals by $85.87 \%$ of the respondents, whereas $14.13 \%$ of them indicated Eubacterium and Prevotella spp. as such a cause (fig. 8).

Fig. 8. Percentage distribution of responses regarding the microorganisms whose presence is associated with the presence of pain in infected root canals

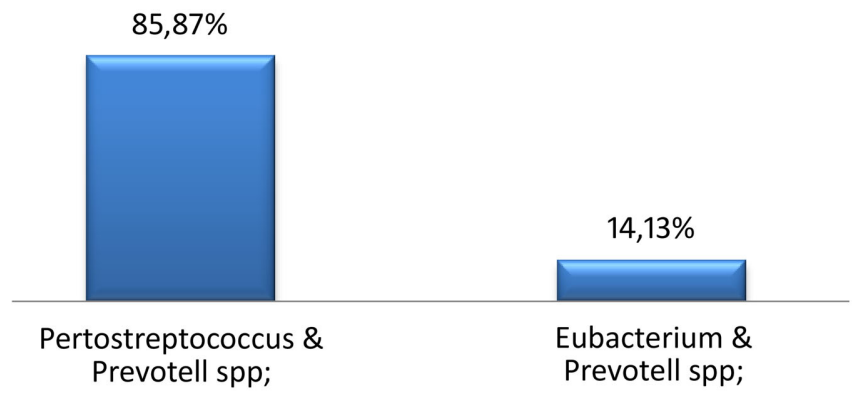

In the case of a persistent endodontic infection that is hardly affected by medications, it is often necessary to take material for microbiological examination from the root canal. Various laboratory tests are used to isolate and identify pathogenic microbial strains. The largest percentage of respondents, $68.48 \%$, indicated nutrient agar plating as the basic identification test (fig. 9).

Fig. 9. Percentage distribution of responses regarding the types of laboratory tests/methods used to prove a bacterial infection

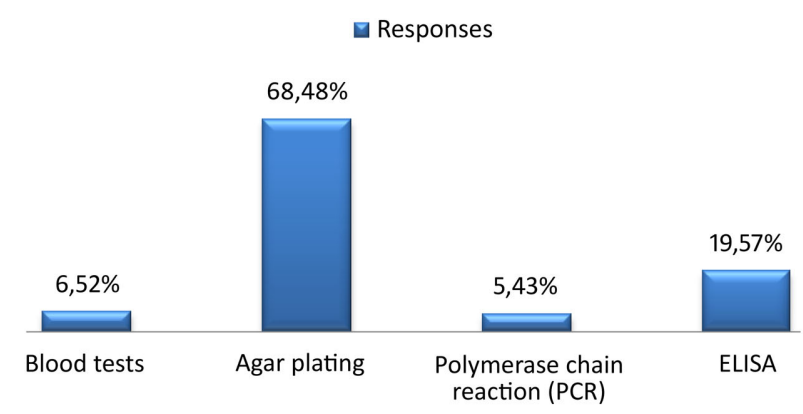

$48.91 \%$ of the respondents indicated the presence of a continuous, unabated exudation from the root canal as grounds for carrying out microbiological examination. $28.26 \%$ indicated the need for such examination as grounds for producing an antibiogram. $18.48 \%$ considered as grounds the continuous endodontic treatment without a good final healing effect. And $4.35 \%$ believed that microbiological examination is needed in patients suffering from general diseases (fig. 10).

Fig. 10. Percentage distribution of responses regarding the cases where there are grounds for conducting microbiological examination

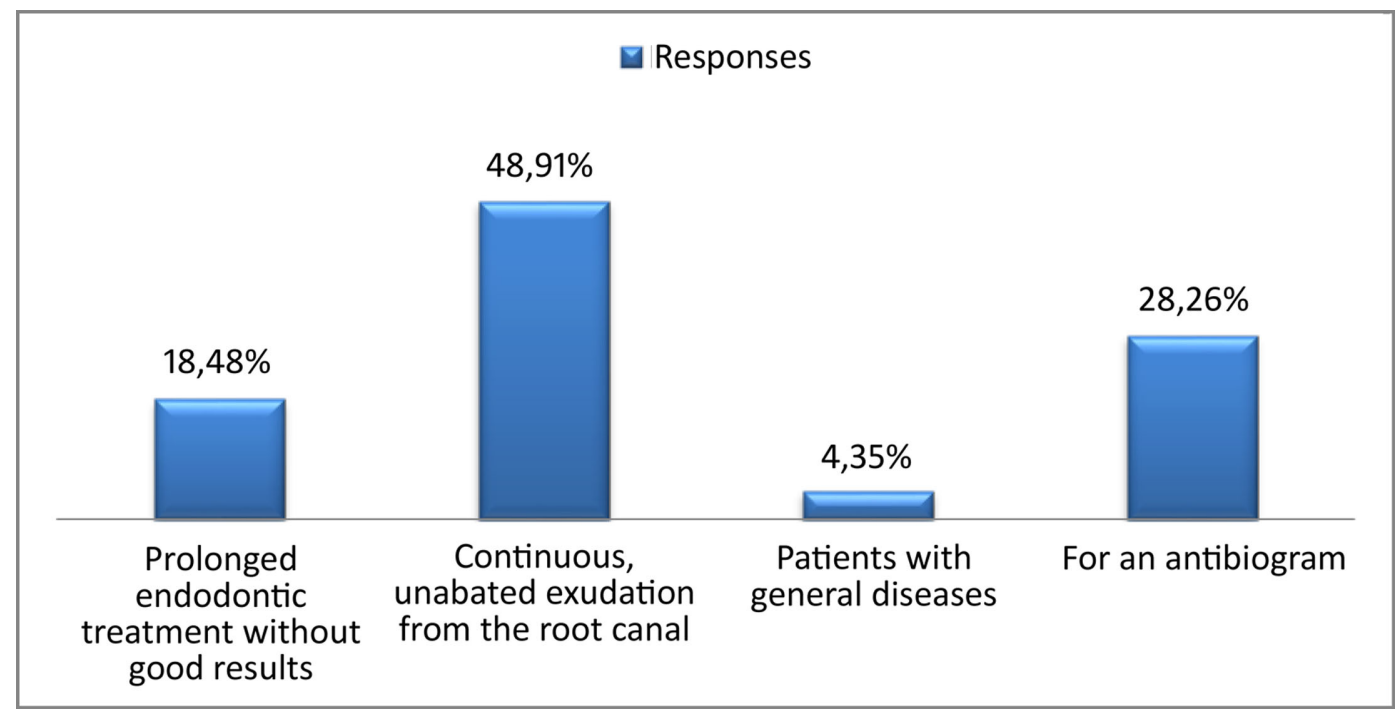


Sometimes, the root canal may have no exudate but may exhibit strong pain symptomatics that is hardly affected by medications. In these cases, when the root canal is dry, the dentin wall is scraped off with a sterile file, after the root canal has been filled with a saline solution or a liquid transport medium. $52.17 \%$ of respondents indicated that it is necessary to use a transport medium followed by scraping the root wall with a sterile file and taking material for microbiological examination with a sterile paper point. $28.26 \%$ consider that a saline solution should be placed in the root canal, and $19.57 \%$ indicate that only scraping the root wall with a file, followed by taking material for microbiological examination with a paper point is an adequate means of treatment in this case (Fig. 11).

Fig. 11. Percentage distribution of responses regarding the way the material is taken for microbiological examination from a dry root canal and pain symptomatics

\section{$\square$ Responses}

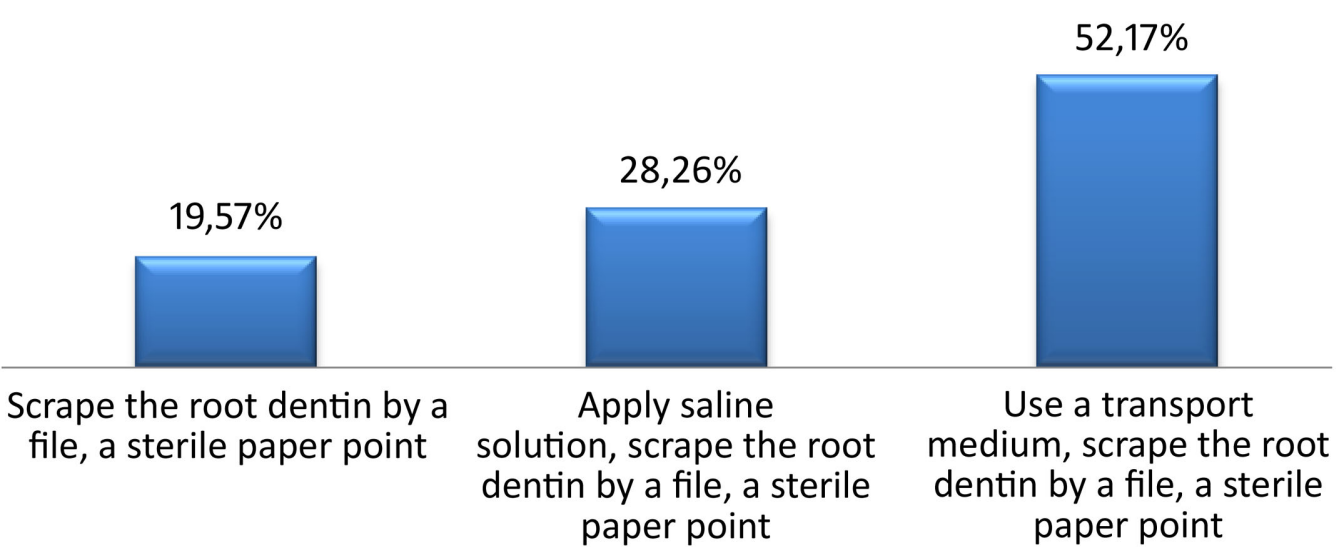

\section{DISCUSSION}

According to their anatomic location, endodontic infections can be classified into intraradicular and extraradicular. Intraradicular infections can, in turn, be subdivided into three categories depending on when the participating microorganisms established themselves in the root canal: primary, secondary and persistent. The composition of the microbiota may vary depending on the different types of infections and the different forms of apical periodontitis. Sophisticated culture and molecular biology techniques have revealed the polymicrobial nature of endodontic infections, with an obvious dominance of obligate anaerobic bacterial species in primary infections. At a broader, taxonomic level, endodontic bacteria are divided into nine types, namely: Firmicutes, Bacteroidetes, Spirochaetes, Fusobacteria, Actinobacteria, Proteobacteri, Synergistetes, TM7 and SR1. Data from studies using molecular-DNA sequencing show a high prevalence of still uncultivated species: about $40 \%$ to $60 \%$ of the endodontic microflora consists of bacteria that are not yet cultivated and characterized $[12,17,18]$. Furthermore, the bacterial profiles of endodontic microbiota vary from individual to individual $[12,19]$, suggesting that apical periodontitis has a heterogeneous etiology leading to a variety of bacterial combinations that may play a role in the causation of the medical condition [20].

Microorganisms that initially invade and colonize the necrotic pulp tissue cause a primary intraradicular infection [21]. The invading microorganisms can be involved at the earlier stages of inflammation and further necrosis of the pulp, or they can be latecomers that take advantage of the environmental conditions in the root canal after pulp necrosis. Various enteric bacteria as Klebsiella, Enterobacter and enterococci are commonly isolated pathogens from teeth with primary endodontic infections [22, 23, 24, 25]. Enterococci are considered to be the most abundant gram-positive cocci colonizing the intestines, and E. faecalis (facultative anaerobic grampositive cocci) are some of the most common bacteria in various periapical/periradicular diseases, associated with failure of endodontic treatment [26].

Although chemical and physical factors may cause periapical inflammation, a great deal of scientific evidence suggests that the endodontic infection is essential for the emergence, progression and persistence of various forms of apical periodontitis $[2,27]$. In various studies, primary root canal infection in untreated canals was found to be polymicrobial with approximately the same ratios between gram-positive and gram-negative species but dominated by obligate anaerobes [28, 29, 30, 31]

Although about 1000 different types of bacteria [32] have been reported in the oral cavity and each person's mouth may contain about 100 to 200 microbial taxa, only a limited range of these bacteria is present in an infected canal [33]. This indicates that there should be certain selective conditions in the root canal system that favor the existence of some species and inhibit the development and reproduction of other species [31]. The main environmental factors that influence the microbiota composition in a root canal with a necrotic pulp are oxygen pressure and oxidation-reduction potential, the type and amount of available nutrients and bacterial interactions [21]. As re- 
gards apical periodontitis, $41.30 \%$ of the students have indicated that the isolated microbial strains could be over 300 .

Microorganisms that initially invade and colonize the necrotic pulp tissue cause a primary intraradicular infection. Primary infections are characterized by a mixed bacterial consortium composed of 10 to 30 bacterial species and $10^{3}$ to $10^{8}$ bacterial cells per a root canal $[13,21$, 34 ]. Although there is evidence that anaerobic gram-negative bacteria are the most common microorganisms in primary endodontic infections, gram-positive bacteria, some of which have very high prevalence rates, have also been found in the mixed endodontic consortium. The most commonly found types of gram-positive bacteria include: Streptococcus (e.g. Str. anginosus), Peptostreptococcus (P. anaerobius, P. stomatis), Actinomyces (e.g. A. israelii), Filifactor (e.g. F. alocis), Olsenella (e.g. O. uli), Parvimonas (e.g. P. micra), Propionibacterium (e.g. P. propionicum, P. acnes), etc. [17, 35, 36, 37].

Microorganisms other than bacteria, as for example fungi, have occasionally been found in endodontic infections. Fungi and Candida spp. in particular are eukaryotic microorganisms that are detected by a light and scanning microscope only sporadically in teeth with primary endodontic infections, but the incidence of their detection in persistent and secondary infections varies from $3 \%$ to $18 \%$ of the cases [21, 38, 39].

Both Enterococcus faecalis and Candida albicans have a number of properties that allow them to survive in treated canals, including resistance to intracanal medicaments and abilities to form biofilms, enter dentinal tubules and survive long in nutrient-poor environments [21, 40]. In this survey, $19.57 \%$ indicated Enterococcus faecalis as a pathogen associated with the failure of endodontic treatment.

Gram-negative bacteria, which are common in primary intraradicular infections, are usually eliminated by endodontic treatment because they are very sensitive to strong oxidizing agents, such as sodium hypochlorite. Most studies on this subject have clearly shown the higher occurrence of gram-positive bacteria (e.g., streptococci, lactobacilli, E. faecalis, O. uli, Parvimonas micra, $P$. alactolyticus, and Propionibacterium) in both post-instrumentation and post-medication samples [41, 42]. Teeth with treated root canals are nine times more likely to harbor $E$. faecalis than teeth with a primary infection [39].

This supports the thesis that gram-positive bacteria can be more resistant to antimicrobial measures taken and have the ability to adapt to the harsh conditions of the surrounding environment in mechanically and chemically treated root canals [21].

Gram-negative bacteria appear to be the most common microorganisms in primary endodontic infections. Bacteria of the genus Prevotella (e.g., P. intermedia, $P$. nigrescens, $P$. baroniae and $P$. tannerae) are gram-negative rods or cocci. They are common causes of upper respiratory tract infections, brain and lung abscesses, empyema, tubo-ovarian abscesses, and in root-canal infections of the teeth they are most commonly associated with peptostrep- tococci and other anaerobic gram-positive bacteria, Fusobacterium (e.g., F. nucleatum) and other facultative-anaerobic species of the normal flora. They produce endotoxins, and their presence is associated with pain in acute inflammatory processes of the periapex of the teeth [21, 44].

Bacteria of the genus Peptostreptococcus (P.magnus, $P$. micros, $P$. prevotii) are anaerobic gram-positive cocci, varying in shape and size $(0.5-2.0 \mu \mathrm{m})$, part of the normal flora of the skin and the mucous membrane of the oral cavity, the large intestine and the genital organs. The species of the former Peptococcus genus are also included to them now. In association with other anaerobic and facultative anaerobic bacteria, they cause infections to the soft tissues (gangrene), the bones (osteomyelitis) and the joints; endocarditis [44].

Eubacteria are also so gram-positive, anaerobic nonspore-forming rod-shaped bacteria. They inhabit the oral cavity and the pharynx, the intestinal tract and the vaginal mucous membrane. Like other anaerobic bacteria, they grow in oxygen-free environments, growing on specially enriched nutrient media for 2-3 days and more [44].

In general, nutrient media are artificially created substrates containing the necessary sources of $\mathrm{C}, \mathrm{N}, \mathrm{P}, \mathrm{H}$, $\mathrm{O}$ and other elements, growth factors, etc. With its chemical composition, $\mathrm{pH}$ and other properties, the nutrient medium must create conditions that meet the requirements of the microbial species and favor its growth and reproduction. As a source of carbon, bacteria most often use sugars, multivalent alcohols, acids, etc. The optimum temperature for cultivating pathogenic bacteria is about $37^{\circ} \mathrm{C}$, but there are also exceptions. The optimum $\mathrm{pH}$ for the development of most pathogenic bacteria is about $7.2-7.4$, but they can also develop within the range of $6.8-8.0$. An important role in the composition of the nutrient medium is played by the presence of sodium chloride $(\mathrm{NaCl})$, the optimal concentration of which ranges between $0.5 \%$ and $0.8 \%$. This concentration provides optimum osmotic pressure (isotony) in the nutrient medium and conditions for normal transport of nutrient substances in cultivating pathogenic bacteria [44].

The greatest achievement in molecular biology, and in genetic engineering particularly, is the polymerase chain reaction (PCR). The PCR is a method for in vitro DNA amplification. It was discovered by Karry Mullis, and the scientist was awarded the Nobel Prize for it in 1993. The reaction is carried out in special apparatuses, called thermal cyclers, in which the temperature required for the reaction step is created by a given program at specified times. Each cycle begins with heating to $94^{\circ} \mathrm{C}$ to denature the doublestranded DNA fragments, which leads to the separation of the two strands. Nucleotides (ATP, GTP, CTP, TTP), which are a source of energy, and nucleosides for DNA synthesis, a thermostable DNA, Taq-polymerase, primers and a DNA matrix, are present in the reaction mixture. The PCR is an extremely sensitive method, which can prove the DNA of single microorganisms in a particular material. Today, it is widely used in research and medical laboratory diagnostics [44]. 


\section{CONCLUSIONS}

On the basis of the results obtained, we consider that it is necessary to increase students' knowledge regarding: (1) species characterization of microorganisms at different nosological units, (2) the ways of taking material for microbiological examination, transportation of samples to a relevant specialized microbiological laboratory for analysis and an antibiogram, and (3) good knowledge of the various therapeutic agents (including antibiotics) and their pre- scriptions in certain nosological units

The pressure exerted by patients and the community as a whole for a quicker and painless intervention on behalf of the dentist is also a factor that may affect overprescription of medications and antibiotics by dental practitioners. It is therefore important for dental students to be trained more effectively, including the way they deal with patients' unreasonable expectations and requirements.

\section{REFERENCES:}

1. Radeva E. [Therapeutic treatment of microflora and pain in the initial phase of acute apical periodontitis without exudation in the root canal] [dissertation]. PhD, MU Sofia, Bulgaria; 2012 [in Bulgarian].

2. Lee LW, Lee YL, Hsiao SH, Lin HP. Bacteria in the Apical Root Canals of Teeth With Apical Periodontitis. J Formos Med Assoc. 2017 Jun; 116(6):448-456. [PubMed]

3. Siqueira JF Jr, Rôças IN. Microbiology of apical periodontitis. Ørstavik D, Pitt Ford T, editors. Essential endodontology. 2nd ed. Oxford: Blackwell Munksgaard Ltd; 2008: 488.

4. Cowpe J, Plasschaert A, Harzer W, Vinkka-Puhakka H, Walmsley AD. Profile and competences for the graduating European dentist - update 2009. Eur J Dent Educ. 2010 Nov;14(4): 193-202. [PubMed]

5. De Moor R, Hülsmann M, Kirkevang LL, Tanalp J, Whitworth J. Undergraduate Curriculum Guidelines for Endodontology. Int Endod J. 2013 Dec;46(12):1105-14. [PubMed]

6. Mainjot A, D'Hoore W, Vanheusden A, Van Nieuwenhuysen JP. Antibiotic prescribing in dental practice in Belgium. Int Endod J. 2009 Dec;42(12):1112-7. [PubMed]

7. Martín-Jiménez M, MartínBiedma B, López-López J, AlonsoEzpeleta O, Velasco-Ortega E, Jiménez-Sánchez MC, et al. Dental students's knowledge regarding the indications for antibiotics in the management of endodontic infections, Int Endod J. 2018 Jan;51(1):118-127. First published: April 2017. [PubMed]

8. Peric M, Perkovic I, Romic M, Simeon P, Matijevic J, Mehicic GP, et al. The pattern of antibiotic prescribing by dental practitioners in Zagreb,
Croatia. Cent Eur J Public Health. 2015 Jun;23(2):107-13. [PubMed]

9. Puryer J, Amin S, Turner M. Undergraduate confidence when undertaking root canal treatment and their perception of the quality of their endodontic education, Dent J (Basel) Dec 26;5(1). [PubMed]

10. Siqueira JF Jr, Rôças IN, Alves FR, Silva MG. Bacteria in the apical root canal of teeth with primary apical periodontitis. Oral Surg Oral Med Oral Pathol Oral Radiol Endod. 2009 May;107(5):721-6. [PubMed]

11. Siqueira J Jr, Rôças I. Community as the unit of pathogenicity: An emerging concept as to the microbial pathogenesis of apical periodontitis. Oral Surg Oral Med Oral Pathol Oral Radiol Endod. 2009 Jun;107(6): 8708. [PubMed]

12. Sakamoto M, Rôças IN, Siqueira JF Jr, Benno Y. Molecular analysis of bacteria in asymptomatic and symptomatic endodontic infections, Oral Microbial Immunol 2006 Apr;21(2):112-22. [PubMed]

13. Vianna ME, Horz HP, Gomes BP, Conrads G. In vivo evaluation of microbial reduction after chemo-mechanical preparation of human root canals contained necrotic pulp tissue. Int Endod J. 2006 Jun;39(6):484-92. [PubMed]

14. Ingle J, Bakland L. Endodontics. 5th ed., 2002, BC Decker Inc. Hamilton, London, pp. 67-74.

15. Siqueira JF Jr, Rôças IN, Souto R, de Uzeda M, Colombo AP. Actinomyces species, streptococci and Enterococcus faecalis in primary root canal infections. J Endod. 2002 Mar;28(3): 168-72. [PubMed]

16. Rôças IN, Siqueira JF Jr, Santos KR. Association of Enterococcus faecalis with different forms of periradi- cular diseases. J Endod. 2004 May;3 0(5):315-20. [PubMed]

17. Munson MA, Pitt-Ford T, Chong B, Weightman A, Wade WG. Molecular and cultural analysis of the microflora associated with endodontic infections. J Dent Res. 2002 Nov; 81(11):761-6. [PubMed]

18. Ribeiro AC, Matarazzo F, Faveri M, Zezell DM, Mayer MP. Exploring bacterial diversity of endodontic microbiota by cloning and sequencing 16S rRNA. J Endod. 2011 Jul; 37(7):922-6. [PubMed]

19. Siqueira JF Jr, Rôças IN, Rosado AS. Investigation of bacterial communities associated with asymptomatic and symptomatic endodontic infections by denaturing gradient gel electrophoresis fingerprinting approach. Oral Microbiol Immunol, 2004 Dec;19(6):363-70. [PubMed]

20. Provenzano JC, Rôças IN, Tavares LF, Neves BC, Siqueira JF Jr. Short-chain fatty acids in infected root canals of teeth with apical periodontitis before and after treatment. J Endod. 2015 Jun;41(6):831-5. [PubMed]

21. Torabinejad M, Fouad R, Walton R. Endodontics. Principles and practice. 5th Edition. Elsevier Saunders. 2014.

22. Ferrari P, Cai S, Bombana A. Effect of endodontic procedures on enterococci, enteric bacteria and yeasts in primary endodontic infections. Int Endod J. 2005 May 18;38(6):372380. [Crossref]

23. Siqueira JF Jr, Rôças IN, Lopes HP, Magalhães FA, de Uzeda M. Elimination of Candida albicans infection of the radicular dentin by intracanal medications. J Endod. 2003 Aug; 29(8):501-4. [PubMed]

24. Siqueira JF. Jr, Sen BH. Fungi in endodontic infections. Oral Surg 
Oral Med Oral Pathol Oral Radiol Endod. 2004 May;97(5):632-41. [PubMed]

25. Madhu K-S, Mathew S. Review of microbiology of endodontics and molecular identification of microorganisms from endodontic infections. $J$ Otolaryngol ENT Res. 2018 Dec; 10(6):417-420. [Crossref]

26. Chávez de Paz LE, Davies JR, Bergenholtz G, Svensäter G. Strains of E.faecalis differ in their ability to coexist in biofilms with other root canal bacteria. Int Endod J. 2015 Oct; 48(10):916-25. [PubMed]

27. Ricucci D, Siqueira JF Jr, Lopes WS, Vieira AR, Rôças IN. Extraradicular infection as the cause of persistent symptoms: a case series. J Endod. 2015 Feb;41(2):265-73. [PubMed]

28. Fouad AF, Barry J, Caimano M, Clawson M, Zhu Q, Carver R, et al. PCR-based identification of bacteria associated with endodontic infections. J Clin Microbiol. 2002 Sep;40(9): 3223-31. [PubMed]

29. Gomes BP, Pinheiro ET, GadêNeto CR, Sousa EL, Ferraz CC, Zaia AA, et al. Microbiological examination of infected dental root canals. Oral Microbiol Immunol. 2004 Apr; 19(2):71-6. [PubMed]

30. Jose F, Siqueira JF Jr, Rôças I. Microbiology and treatment of endodontic infections. Cohen S. and Hargreaves, KM (eds). Pathway of the pulp. 10th ed. Baltimore: CV Mosby

\section{Co; 2011: 572-8.}

31. Sundqvist G, Fidgor D. Life as an endodontic pathogen: Ecological differences between the untreated and root-filled root canals. Endod Topics 2004 June 15;6(1):3-28 [Crossref]

32. Dewhirst FE, Chen T, Izard J, Paster BJ, Tanner AC, Yu WH. The human oral microbiome, J Bacteriol. 2010 Oct;192(19):5002-17. [PubMed]

33. Fouad A. Endoddontic microbiology and pathobiology. Dent Clin North Am. 2017 Jan;61(1):1-15. [PubMed]

34. Tzanetakis G-N, Azcarate-Peril M-A, Zachaki S, Panopoulos P, Kontakiotis E-G, Madianos P-N, et al. Comparison of Bacterial Community Composition of Primary and Persistent Endodontic Infections Using Pyrosequencing. J Endod. 2015 Aug;41(8): 1226-33. [PubMed]

35. Rôças, I-N, Siqueira J-F Jr. Root canal microbiota of teeth with chronic apical periodontitis, J Clin Microbiol. 2008 Nov;46(11):3599-606. [PubMed]

36. Siqueira, J-F Jr, Rôças I-N. Detection of Filifactor alocis in endodontic infections associated with different forms of periradicular diseases, Oral Microbiol Immunol. 2003 Aug;18(4): 263-5. [PubMed]

37. Singh H. Microbiology of Endodontic Infections. J Dent Oral Health. 2016; 2(5):044.

38. Egan MW, Spratt DA, Ng
YL, Lam JM, Moles DR, Gulabivala K. Prevalence of yeasts in saliva and root canals of teeth associated with apical periodontitis. Int Endod J. 2002 Apr; 35(4):321-9. [PubMed]

39. Siqueira JF. Jr, Rôças IN. Polymerase chain reaction-based analysis of microorganisms associated with failed endodontic treatment. Oral Surg Oral Med Oral Pathol Oral Radiol Endod. 2004 Jan;97(1):85-94. [PubMed]

40. Distel JW, Hatton J-F, Gillespie M-J. Bofilm formation in medicated root canals. J Endod. 2002 Oct;28(10): 689-93. [PubMed]

41. Chávez de Paz L-E, Molander A, Dahlén G. Gram-positive rods prevailing in teeth with apical periodontitis undergoing root canal treatment. Int Endod J. 2004 Sep;37(9):579-87. [PubMed]

42. Chu F-C, Leung W-K, Tsang PC, Chow T-W, Samaranayake L-P. Identification of cultivable microorganisms from root canals with apical periodontitis following two-visit endodontic treatment with antibiotics/ steroid or calcium hydroxide dressings, $J$ Endod. 2006 Jan;32(1):17-23. [PubMed]

43. Sedgley C. Endodontic microbiology. 7th Annual Scientific Update and ABE Board Review, 2016:1-124

44. Mitov G, Docheva Y. [Microbiology.] 2nd Edition. [in Bulgarian], Arco, Sofia, Bulgaria 2000: 393.

Please cite this article as: Karayasheva D, Radeva E. A survey done among dental students on their knowledge in endodontic microbiology. J of IMAB. 2020 Apr-Jun;26(2):3045-3052. DOI: https://doi.org/10.5272/jimab.2020262.3045

\author{
Address for correspondence: \\ Assoc. Prof. Elka Radeva, DMD, PhD \\ Department of Conservative Dentistry, Faculty of Dental \\ Medicine, Medical University; \\ 1, Georgi Sofiyski Blvd., 1431 Sofia, Bulgaria. \\ E-mail: eliradeva@abv.bg
}

